\title{
Psychological Distress Among Freshmen University Students
}

\author{
Alfiyan, Alvin ${ }^{1 *}$ Purnama, Ishma Najya Zafira ${ }^{1}$, Youlanda, Wyke ${ }^{1}$, Kaloeti,Dian \\ Veronika Sakti², Sakti, Hastaning ${ }^{2}$. \\ ${ }^{I}$ Master of Psychology, Universitas Diponegoro, Semarang, Indonesia \\ ${ }^{2}$ Family Empowerment Center, Fakultas Psikologi, UniversitasDiponegoro, Semarang, Indonesia \\ [Prof. Soedarto, SH, Kampus Undip Tembalang, Semarang, 50275, Indonesia]
}

*Corresponding author. Email: alvinassegaf.aa@gmail.com

\begin{abstract}
Psychological distress is negative mental health, which can affect a person directly or indirectly over time. The psychological distress that emerges to the new students was related to the transition period, academic, and nonacademic burdens experienced. The sample of this research was 3819 first-year students of Universitas Diponegoro with an age range of $17-22$ years $(M \pm S D=19.27 \pm .637)$ from the fields of business economics, language studies, social and political studies, medical science, sciences and mathematics, and engineering. Data collection was carried out in 2019. The sampling technique used random sampling. The scale used in this study was the General Health Questionnaire (GHQ-12) (12 items, $\alpha=0.802)$ to measure psychological distress. Descriptive analysis, One-Way Anova, and Independent sample T-test used in this study. The results of the study found that there were significant differences in the psychological distress status of non-science and science students at Universitas Diponegoro $(\mathrm{F}=13.461, p=.000<.05)$. From the data, it can be seen that participants from the science study program group were in the healthy category $(88 \%)$ unhealthy $(12 \%)$, while participants from the non-science study program group were in the healthy $(85 \%)$ and unhealthy $(15 \%)$ category. The implications of the research results will be discussed further. Recommendations for the results of this study can be useful for university policyholders and student advisers regarding the importance of overcoming psychological disorders for freshmen university students.
\end{abstract}

Keywords: Psychological distress, Freshmen University Students, Science, and Social Sciences.

\section{INTRODUCTION}

A period that creates considerable stress in the lives of students and has been found to increase their distress has often been passed the transition to college which stressors are related to life transitions and the resulting distress appears to have the capacity to erode self-esteem [1].The university students usually face multiple stressors such as academic demands, workload, and pressure to succeed, teacher and parent's pressure, financial burden, and worry about the future that can lead to develop a psychological problem in students and negatively affect their academic performance[2]. Fram \& Bonvillian [1] first-year university students are obliged to deal with the stressors that are related to these new academic demands such as adapting to new learning environments and methods of instruction, receiving less individual support from instructors, competing for grades, trying to effectively manage more demands for their time, and engaging in the selfregulation that is necessary to develop their academic skills. The factors associated with university student psychological distress indicated sociodemographic and situational factors, academic and performancerelated factors, as well as personality and individual difference factors as being important [3]. The purpose of this study was to determine the effect of the participant's description on the participants' psychological pressure. 


\subsection{Previous research}

The results of the [1] study in the southern region of Israel described that psychological distress may have led to greater distress, more functional impairment, and lower self-esteem. While in Pakistan study showed that student of Engineering; Medical \& Social Science are at risk of depression, anxiety, and stress which their life satisfaction levels are similar to other students whereas their happiness levels are lower and that life satisfaction has a highly significant negative correlation with like depression, anxiety \& stress [2]. The research in Central California mentioned psychological distress such as depression and anxiety can influence the professional development of students and also negatively impact on their academic performance [4]. Avoidant coping strategies such as denial, behavioural disengagement, or self-distraction can negatively impact their psychological health and intensify the frequency of experiencing symptoms of psychological distress such as depression, anxiety, and stress are included in the observation in this study [4]. Syrian medical students suffer from high rates of psychological distress. Females, second-year students, and those with "insufficient" personal income were the most affected.

\section{METHOD}

\subsection{Research Participants}

The samples of this research were first-year Universitas Diponegoro students of 2019 from the fields of economics and business, cultural study, socio-political study, medical science, science and mathematics, and engineering. Participants in this study were 3,819 students randomly selected from six faculties at Universitas Diponegoro. The participants were students aged 17-22 years $(\mathrm{M} \pm \mathrm{SD}=19.27 \pm$ .637). Sampling used purposive sampling.

\subsection{Research Instruments}

Data collection methods in this study used a psychological scale (GHQ-12). General Health Questionnaire (12 items, $\alpha=$, 802) was applied to identify individual psychological disorders in recent weeks. Each item on the scale consisted of four statements which it deems most appropriate to itself as better than usual, the same as usual, less than usual, and very less than usual, with a response score: $0-0-1-1$, ending by adding all items on a scale ranging from 0 to 12. Interpretation of distress conditions was that individuals with a score less than or equal to five have a healthy psychological condition, while individuals with a score greater than or equal to six have an unhealthy psychological condition.

\subsection{Data collection}

The data was collected by distributing questionnaires to students in the six fostered faculties by visiting the participants in person. Participants in this study were voluntary by signing the informed consent that was already given. After filling in the informed consent, participants were directed to fill out a questionnaire.

\subsection{Research Data Analysis}

Survey data were analysed with the help of the Statistical Package for Social Sciences program for Windows version 25.0. Descriptive, One Way ANOVA analysis, and Independent sample T-test analysis used in this study. Information on demographic and social characteristics was obtained using descriptive statistics. One Way ANOVA analysis was used to determine study program groups (science and non-science) based on psychological distress and Independent sample T-test to check the effect of psychological distress of participants.

\section{RESULT}

\subsection{Demographic Description of Research Participants}

A total of 3.819 students completed the survey resulting in a $100 \%$ response rate. Researchers were sensitive to the fact that students volunteered to participate and in doing so had expressed a desire to share their stressful experiences. Demographic Table 1 presents the demographic profile of the sample consisting of more women $(59 \%)$ than men $(41 \%)$. The majority $(65 \%)$ of respondents were 19 years old. Students were enrolled in the medical study program (10\%), engineering study program $(31 \%)$, science and mathematics study program $(55 \%)$, social and political study program (9\%), language science study program (17\%), and business economics study program (15\%). A detailed description of the demographic picture of research participants can be seen in Table 1. 
Table 1. Result of Descriptive Test

\begin{tabular}{|c|c|c|}
\hline \multirow{2}{*}{ Category } & \multicolumn{2}{|c|}{ Total } \\
\hline & Amount & $\%$ \\
\hline \multicolumn{3}{|l|}{ Gender } \\
\hline Male & 1554 & $41 \%$ \\
\hline Female & 2265 & $59 \%$ \\
\hline \multicolumn{3}{|l|}{ Age } \\
\hline 17 & 3 & $0 \%$ \\
\hline 18 & 219 & $6 \%$ \\
\hline 19 & 2496 & $65 \%$ \\
\hline 20 & 958 & $25 \%$ \\
\hline 21 & 130 & $3 \%$ \\
\hline 22 & 13 & $0 \%$ \\
\hline \multicolumn{3}{|l|}{ Faculty } \\
\hline $\begin{array}{l}\text { Faculty of Economics } \\
\text { and Business }\end{array}$ & 566 & $15 \%$ \\
\hline $\begin{array}{l}\text { Faculty of Cultural } \\
\text { Studies }\end{array}$ & 667 & $17 \%$ \\
\hline $\begin{array}{l}\text { Faculty of Social and } \\
\text { Political Science }\end{array}$ & 356 & $9 \%$ \\
\hline Medical Science & 398 & $10 \%$ \\
\hline $\begin{array}{l}\text { Faculty of Science } \\
\text { and Mathematics }\end{array}$ & 650 & $55 \%$ \\
\hline $\begin{array}{ll}\text { Faculty } & \text { of } \\
\text { Engineering } & \end{array}$ & 1182 & $31 \%$ \\
\hline \multicolumn{3}{|l|}{ Selection Pathways } \\
\hline IUP & 55 & $1 \%$ \\
\hline Kemitraan & 27 & $1 \%$ \\
\hline SBMPTN & 1869 & $49 \%$ \\
\hline SBUB & 57 & $1 \%$ \\
\hline SNMPTN & 1002 & $26 \%$ \\
\hline TesLokal & 7 & $0 \%$ \\
\hline $\mathrm{UM}$ & 802 & $21 \%$ \\
\hline \multicolumn{3}{|l|}{ Father's Education } \\
\hline $\begin{array}{c}\text { Primary education } \\
\text { level }\end{array}$ & 1770 & $46 \%$ \\
\hline $\begin{array}{c}\text { Secondary education } \\
\text { level } \\
\end{array}$ & 1368 & $36 \%$ \\
\hline $\begin{array}{c}\text { Upper Education } \\
\text { Level }\end{array}$ & 681 & $18 \%$ \\
\hline \multicolumn{3}{|l|}{ Mother's Education } \\
\hline Primary education & 1535 & $40 \%$ \\
\hline
\end{tabular}

\begin{tabular}{ccc}
\hline level & & \\
\hline $\begin{array}{c}\text { Secondary education } \\
\text { level }\end{array}$ & 1409 & $37 \%$ \\
\hline $\begin{array}{c}\text { Upper Education } \\
\text { Level }\end{array}$ & 875 & $23 \%$ \\
\hline
\end{tabular}

\subsection{Result of One-Way Anova}

One-way Anova test results show that the calculated $\mathrm{F}$ value of the gender variable is .651 $(p=$ $.420)$ and the most participants are women, the selection pathways variable $\mathrm{F}=4.149(p=.000)$ most students are accepted through the SBMPTN selection pathways. The study program variable was $\mathrm{F}=$ $20.221(p=, 000)$. The father's education variable was $\mathrm{F}=1.179(p=.308)$, the mother's education variable was $\mathrm{F}=.288(p=.750)$. It can be explained that age, study program, and selection pathway have a value of $\mathrm{p}=.000<.05$, which means that there is an influence between study program, pathways selection, and psychological distress, while other variables do not affect psychological distress. Variables of age, study program, and selection path with sig. $<0.05$, means that the hypothesis is accepted. In other words, there is a significant difference between age, course of study, and psychological distress. For more details, see Table 2.

Table 2. Result of One-way Anova

\begin{tabular}{lrrrr}
\hline & df & $\begin{array}{c}\text { Mean } \\
\text { Square }\end{array}$ & F & Sig. \\
\hline Study Program & 1 & 137.374 & 20.221 & .000 \\
\hline Gender & 1 & 4.447 & .651 & .420 \\
\hline Age & 5 & 17,608 & 2.505 & .028 \\
\hline $\begin{array}{l}\text { Selection } \\
\text { Pathways }\end{array}$ & 6 & 28.190 & 4.149 & .000 \\
\hline $\begin{array}{l}\text { Father's } \\
\text { Education }\end{array}$ & 2 & 8.051 & 1.179 & .308 \\
\hline $\begin{array}{l}\text { Mother's } \\
\text { Education }\end{array}$ & 2 & 1.969 & .288 & .750 \\
\hline
\end{tabular}

\subsection{Result of Independent Samples T-Test}

Independent samples T-test was used General Health Questionnaire (GHQ-12) or psychological distress. The results of the independent samples $t$-test showed that the $\mathrm{F}$ value is 13.461 and $p=.000<.05$, so $\mathrm{H} 0$ is rejected, meaning that the two populations have 
different variants, namely individuals with healthy and unhealthy conditions, so the t-test analysis uses the assumption of equal variance not assumed. From the t-test column, it can be seen that the $p$-value (2tailed) on the equal variance is not assumed $p=, 000$ $<.05$. Thus, there is a difference between the two variants, the difference lies in the individual variant in a healthy condition and an individual with an unhealthy condition. From those data, the participants from the science faculty were in the healthy category $(88 \%)$ unhealthy $(12 \%)$, while the non-science participants were in the healthy category $(85 \%)$ and unhealthy (15\%). For more details, see Table 3.

Table 3. Result of Independent T-test

\begin{tabular}{|c|c|c|c|c|c|c|}
\hline & & $\begin{array}{r}\text { Leve } \\
\text { Test } \\
\text { Equi } \\
0 \\
\text { Varia }\end{array}$ & $\begin{array}{l}\text { ne's } \\
\text { for } \\
\text { lity } \\
\text { nces }\end{array}$ & & & \\
\hline & & $\mathrm{F}$ & $\begin{array}{l}\mathrm{Si} \\
\mathrm{g} .\end{array}$ & $\mathrm{t}$ & $\mathrm{df}$ & $\begin{array}{c}\text { Sig. } \\
(2- \\
\text { taile } \\
\text { d) } \\
\end{array}$ \\
\hline $\mathrm{GHQ}_{-}$ & $\begin{array}{c}\text { Equal } \\
\text { varian } \\
\text { ces } \\
\text { assum } \\
\text { ed }\end{array}$ & $\begin{array}{c}13.4 \\
61\end{array}$ & $\begin{array}{c}, 00 \\
0\end{array}$ & $\begin{array}{l}4.4 \\
97\end{array}$ & 3.817 & ,000 \\
\hline 12 & $\begin{array}{c}\text { Equal } \\
\text { varian } \\
\text { ces } \\
\text { not } \\
\text { assum } \\
\text { ed }\end{array}$ & & & $\begin{array}{c}4.4 \\
50\end{array}$ & $\begin{array}{c}3288.9 \\
65\end{array}$ & ,000 \\
\hline
\end{tabular}

\subsection{Psychological distress}

Based on the results of the research, we found influences and differences between age, study program, and selection pathways with psychological disorders. The age of the participants in this study was 17-22 years, with the highest level of distress at 22 years. Based on the results of a study by the Department of Health of Western Australia, [6] found that the population aged 18 to 24 years had a higher level of distress than other age groups. Psychological distress included negative thoughts and feelings such as feelings of discomfort, frustration, irritability, worry, and anxiety [7]. Distress can cause negative emotions or negative effects, for example, sadness, disappointment, hopelessness, depression, helplessness, frustration, anger, resentment, and other negative emotions [8]. One form of channeling negative emotions is self-injurious behaviour or SIB, while the prevalence of SIB among adolescents is $17.2 \%$ and young adults are $13.4 \%$ Swannell, et al. [9] which supports the results of the study. Ages 1824 were included in the developmental stages of late adolescence and early adulthood. [10] stated a brief study that the age of adolescence ends around 18 to 22 years. The majority of students were included in the late adolescent category. Camenius [11]also stated that the age of 18 to 24 was in higher education.

From the study program, students from the science study group had lower psychological distress. This refers to the results of research conducted by [12] which states that the level of depression of Medicine Undergraduate students in the Universitas Diponegoro is $60.4 \%$ showing that, most of them were not experience depression. Research that has been conducted by [13] said the factors that influence depression, stress, and anxiety in students are pressure to succeed, academic performance, postgraduation planning, sleep quality, relationship friends, relationships with family, overall health, body image, and self-esteem. [14] found that there was a significant negative relationship between academic adjustment and stress tendencies, so the students of the Faculty of Medicine who were able to adapt to academic demands were less likely to experience stress.

However, in general, groups of students from science and non-science study programs are still in the psychologically healthy category. This can be obtained by several factors, such as the results of research by [15] which found that social support and personal motivation in students are directly or indirectly bridged by a feeling of belonging and psychological pressure. It is unrelated to their academic activities, so social support, selfconfidence, feelings of belonging, and psychological pressure do not represent a predictable value for academic activity. However, their results indicated that social support and personal motivation were significantly opposite to the psychological distress 
they faced. This indicates that the more of having social support and personal motivation, there less psychological pressure for students.

The results of other research also proved our study, it can be seen in [16] study; there was a negative relationship between resilience and psychological distress on psychology and medical students. Some studies worked as the same as [17] [18] related to the relationship between resilience and psychological distress described the negative results, which means that the higher of the resilience, the level of psychological distress will get lower, and the lower level of resilience as the individual has, it will appear the higher level of psychological distress. We can summarize that students from the science and non-science study groups may have a high level of resilience because the results show that they are still in the psychologically healthy category.

Besides, low psychological distress in new students can occur due to social support from peers, such as the results of research from [19] which explain that peer social support is proven to have a negative relationship with distress in first-year students of Universitas Diponegoro. When new students get good enough social support from their peers, they will have quite low psychological distress. Having a sense of humour also one way to reduce the level of stress experienced by a person, according to by [20] a sense of humour and stress in new students of the Faculty of Psychology, University of Surabaya has a negative relationship with the level of stress. The correlation is strong enough, which means that when the individual has a sense of humour, the individual's stress level will below.

The individual's ability to manage stress and coping skills can also play a role in reducing stress levels in new students. [21] explained that new students of the Faculty of Medicine at UISU experience stress to a low degree because they have the right coping skills. [22] mentions stress management in students such as being alert to stress, doing time outs, planning self-care, planning time management, solving joint problems, and seeking support that can play a role in reducing stress levels. The factors above can produce lower psychological pressure on students.

\subsection{Conclusion}

Psychological distress is a negative emotional experience experienced by individuals such as sadness, disappointment, hopelessness, depression, helplessness, frustration, anger, resentment, and other negative emotions. Low psychological distress is influenced by several factors such as the student's high resilience, social support from friends, the ability to manage stress, and the student's coping skills. However, these factors are not discussed in depth in this study, so this can be a suggestion for further research, to make research on what factors can reduce psychological distress in new students. A limitation of this study is that we included only one measure of GHQ for psychological distress which resulted in a contextual finding that may not be representative of all students and did not address in depth the factors that influence low psychological distress. A further limitation is the use of self-report measures that are vulnerable to socially desirable answers

\section{AUTHORS' CONTRIBUTIONS}

DVSK and HS conceived the presented idea and conducted data collection. AA, INZP, and WY developed the theory and performed the computations. WK, DVSK, HS, INZP verified the analytical methods. All authors discussed the results and contributed to the final manuscript.

\section{ACKNOWLEDGMENTS}

Universitas Diponegoro as a research partner as well as a supporter of funding sources in this research through the Development and Application Research (RPP) program for funding sources other than the Universitas Diponegoro State Budget with SK number: 329-41 / UN7.6.1 / PP / 2020. In addition, the researcher also expressed his gratitude to all Universitas Diponegoro new students had participated as research respondents.

\section{REFERENCES}

[1] A. Besser, V. Zeigler-hill. Positive personality features and stress among first-year university students: Implications for psychological distress, functional impairment, and self-esteem. Self Identity. (2012) 1-21. DOI: $10.1080 / 15298868.2012 .736690$ 
[2] H. Kumar. Psychological distress and life satisfaction among university students. J. Psychol. Clin. Psychiatry. 5(3) (2016) 1-8. DOI: 10.15406/jpcpy.2016.05.00283.

[3] J. Sharp, S.A.Theiler. Review of Psychological Distress Among University Students : Pervasiveness, Implications, and Potential Points of Intervention. Int $\mathrm{J} \mathrm{Adv}$ Counselling. 40 (2018) 193-212. DOI: 10.1007/s10447-0189321-7.

[4] M. Vungkhancing, J.C.Tonsing, K.N. Tongsing. Psychological Distress, Coping, and perceived social support in social work students. Br. J. Soc. Work. (2016) 1-15. DOI: 10.1093/bjsw/bcw145

[5] T. Saadi, S.Z. Addeen, T. Turk, F. Abbas, M. Alkhatib. Psychological distress among medical students in conflicts: A cross-sectional study from Syria. BMC Medical Education (2017) 18. DOI: $10.1186 / \mathrm{s} 12909-017-1012-2$

[6] D. Saunders, A. Daly. Psychological distress in the Western Australian population. 2000 health and wellbeing survey, 3, pp. 3-7.

[7] F. Shaheen, M.S. Alam. Psychological distress and its relation to attributional styles and coping strategies among adolescents. J. Indian Acad. Appl. Psychol, 36(2) (2010) 231-238.

[8] T. Safaria, N.E. Saputra. Manajemen emosi (Sebuah panduan cerdas bagaimana mengelola emosi positif dalam hidup anda), Jakarta: BumiAksara. 2009

[9] K. Hauber, B. Albert, V. Robert. Non-suicidal self-injury in clinical practice. Front Psychol. 10(502) (2019) 1-8.

[10] J.W. Santrock. Remaja. Jakarta: Penerbit Erlangga. 2007

[11] S.W. Sarwono. Psikologi remaja. Jakarta: PT. Rajagrafindo Persada. 2012

[12] O.Martasari, A. Ediati. Harapan orangtua dan depresi pada mahasiswa program studi S1 kedokteran umum. Empati, 7(3) (2018) 835-842.

[13] R. Beiter, R. Nash, M. Mccrady, D. Rhoades, M. Linscomb, M. Clarahan, S. Sammut. The prevalence and correlates of depression, anxiety, and stress in a sample of college students. J. Affect. Disord. 173 (2015) 90-96.

[14] D. Christyanti, D. Mustami'ah, W. Sulistiani. Hubungan antara penyesuaian diri terhadap tuntutan akademik dengan kecenderungan stres pada mahasiswa Fakultas Kedokteran Universitas Hang Tuah Surabaya. Insan 12(3) (2010) 153-159.

[15] S. Handagoon, V. Parvathy, The influence of social support and student's self efficacy on academic engagement of undergraduate students mediated by sense of belonging and psychological distress scholar. Human Sciences. 11(2) (2019) 135.

[16] S. Bacchi, J. Licinio. Resilience and psychological distress in psychology and medical students. Acad Psychiatry. 41 (2017) 185-188. DOI: 10.1007/s40596-016-0488-0.

[17] K. Mahmood, A. Ghaffar. The relationship between resilience, psychological distress, and subjective well-being among dengue fever survivors. Global Journals Inc. 14(10) (2014) 13-24.

[18] A.M. Pidgeon, N.F. Rowe, N. F., P. Stapleton, H.B. Magyar, B. C. Lo. Examining characteristics of resilience among university students: an international study. Open J Soc Sci. 2 (2014) 14-22.

[19] N. Pramestuti, K. Dewi, K, Distres ditinjau dari dukungan sosial teman sebaya pada mahasiswa tahun pertama Universitas Diponegoro. Empati, 3(4) (2015) 442-452.

[20] S.P.S. Aquarista. Hubungan sense of humor dengan stres pada mahasiswa baru Fakultas Psikologi, 2014, J Il Mahasiswa Universitas Surabaya. 3(1).

[21] M. Bania, R.S. Dwi. Derajat stres mahasiswa baru Fakultas Kedokteran, Universitas Islam Sumatera Utara T.A 2016-2017, 2018, Jurnal Kedokteran STM. P- ISSN 2614 - 610X.

[22] S. Luh. Manajemen Stres Mahasiswa Baru, 2012, J. Kes. Prima. 6 (2) (2012). 